\title{
The effect of using a co-solvent in the extraction process on the performance and quality of the obtained raffinates
}

\author{
Wpływ zastosowania współrozpuszczalnika w procesie ekstrakcji na wydajność i jakość \\ uzyskanych rafinatów
}

\author{
Artur Antosz, Stefan Ptak \\ Oil and Gas Institute - National Research Institute
}

\begin{abstract}
During the investigations solvent refining tests were conducted using co-solvents of different concentration as well as carrying out a reference process without a co-solvent. The laboratory stand used for modelling the technological process allowed to carry out the solvent refining continuously, simulating a production process in the petroleum rafinery lube oil plant. The feed stock used in the investigation was fraction obtained during petroleum vacuum distillation serving to produce a base oil. The investigation of the solvent extraction process was conducted using formamide as a co-solvent in the amount of $10 \%(\mathrm{~m} / \mathrm{m})$ and $15 \%(\mathrm{~m} / \mathrm{m})$. In addition, the extraction process without formamide was carried out as a reference process when comparing both the yield of the obtained raffinates and quality of the products received when a co-solvent was applied. In all the solvent refining tests the same technological parameters were applied. Basic physico-chemical properties of the produced raffinates were determined. It was found that despite using the same technological parameters in the extraction processes, changing only the proportion of co-solvent from 0 to $10 \%(\mathrm{~m} / \mathrm{m})$, raffinates of different yield and quality were obtained. The lowest yield was observed during the process in which only furfural was applied, i.e. in the reference process for those with the use of a co-solvent, and during that process a raffinate of $49.7 \%(\mathrm{~m} / \mathrm{m})$ yield was obtained. The highest raffinate yield $-72.2 \%(\mathrm{~m} / \mathrm{m})$ was obtained in the process with $10 \%(\mathrm{~m} / \mathrm{m})$ of formamide. In the process with $5 \%(\mathrm{~m} / \mathrm{m})$ of a co-solvent a raffinate of $62.5 \%(\mathrm{~m} / \mathrm{m})$ yield was obtained. When comparing the performances obtained, it can be stated that an addition of a co-solvent in the proportion of $5 \%(\mathrm{~m} / \mathrm{m})$ will cause $12.8 \%(\mathrm{~m} / \mathrm{m})$ increase in the amount of the raffinate obtained, and $10 \%(\mathrm{~m} / \mathrm{m})$ addition of a co-solvent will bring $22.5 \%(\mathrm{~m} / \mathrm{m})$ increase of the refining process yield. This increase in the raffinate output leaded to with the lowering of its quality in regard to all the investigated parameters.
\end{abstract}

Key words: solvent refining, solvent extraction, co-solvent.

STRESZCZENIE: W trakcie badań przeprowadzono próby rafinacji rozpuszczalnikowej z zastosowaniem współrozpuszczalnika w różnych stężeniach oraz proces odniesienia bez udziału współrozpuszczalnika. Do badań modelujących proces technologiczny wykorzystano stanowisko laboratoryjne umożliwiające prowadzenie procesów rafinacji rozpuszczalnikowej w sposób ciągły, symulujące proces przemysłowy stosowany na bloku olejowym w rafinerii ropy naftowej. Surowcem do badań była frakcja otrzymana podczas destylacji próżniowej ropy naftowej służąca do wytwarzania oleju bazowego. Badania nad procesem ekstrakcji rozpuszczalnikowej prowadzono przy zastosowaniu formamidu jako współrozpuszczalnika w ilości $5 \%(\mathrm{~m} / \mathrm{m})$ i $10 \%(\mathrm{~m} / \mathrm{m})$. Wykonano również proces ekstrakcji bez współudziału formamidu, służący jako proces odniesienia dla porównania wydajności uzyskanych rafinatów i jakości otrzymanych produktów procesu z zastosowaniem współrozpuszczalnika. Dla wszystkich prób rafinacji rozpuszczalnikowej zastosowano takie same parametry technologiczne. Określono podstawowe właściwości fizykochemiczne wytworzonych rafinatów. Analizując uzyskane wyniki, stwierdzono, że pomimo zastosowania tych samych parametrów technologicznych prowadzenia procesów ekstrakcji, zmieniając jedynie udział współrozpuszczalnika od 0 do $10 \%(\mathrm{~m} / \mathrm{m})$, otrzymano rafinaty z różną wydajnością i jakością. Najniższą wydajność odnotowano dla procesu z zastosowaniem samego furfuralu, który był procesem odniesienia dla prób z użyciem współrozpuszczalnika - w trakcie tego procesu uzyskano rafinat $\mathrm{z}$ wydajnością $49,7 \%(\mathrm{~m} / \mathrm{m})$. Najwyższą wydajność rafinatu, na poziomie $72,2 \%(\mathrm{~m} / \mathrm{m})$, osiągnięto dla procesu z 10-procentowym $(\mathrm{m} / \mathrm{m})$ udziałem formamidu. W procesie z udziałem współrozpuszczalnika na poziomie $5 \%(\mathrm{~m} / \mathrm{m})$ uzyskano rafinat z wydajnością $62,5 \%(\mathrm{~m} / \mathrm{m})$. Porównując otrzymane wydajności rafinatów, można stwierdzić, że dodatek współrozpuszczalnika w ilości 5\% $(\mathrm{m} / \mathrm{m})$ wpłynął na zwiększenie ilości otrzymywanego rafinatu o 12,8\% $(\mathrm{m} / \mathrm{m})$, a dodatek współrozpuszczalnika w ilości $10 \%(\mathrm{~m} / \mathrm{m})$ spowodował wzrost wydajności procesu rafinacji o $22,5 \%(\mathrm{~m} / \mathrm{m})$. Zwiększenie wydajności uzysku rafinatu wiązało się z obniżeniem jego jakości we wszystkich badanych parametrach.

Słowa kluczowe: rafinacja rozpuszczalnikowa, ekstrakcja rozpuszczalnikowa, współrozpuszczalnik.

\section{Corresponding author: A. Antosz, e-mail: artur.antosz@inig.pl}

Article contributed to the Editor 11.01.2019. Approved for publication 14.10.2019 


\section{Introduction}

Production of lubricants resulting from petroleum processing belongs to the oldest branches of the petrochemical industry. The feedstocks for lubricant manufacturing are the fractions obtained during distillation under reduced pressure. The boiling temperatures of these fractions usually range from 316 to $593^{\circ} \mathrm{C}$ (Czernożukow, 1969). The obtained vacuum fractions also include some undesired components negativaly effecting the quality of final products of the lube oil plant. To remove undesired components from lube distillates such as polycyclic aromatic hydrocarbons, asphalthene-resin substances and compounds with elements other than carbon and hydrogen, solvent refining processes are applied (Gurewicz, 1975; Podniało, 2002). This method uses the difference in solubility of hydrocarbons in organic solvents. The most important factors in the process are the weight ratio of a solvent to the purified product and the temperature in which the process is conducted. The extraction process is used in a standard lube oil plant of the petroleum refinery where vacuum distillates are being processed into base oils (Sequeira, 1994).

In the base oil production a method of continuous, selective solvent extraction in the countercurrent unit is applied. The extraction unit can be equipped with plates of cascade, bubble-cup or valve type, either with rotational disks or filled up with Białecki, Raschig rings, with cell packings (Bushnell and Fiocco, 1980).

Base oils are mixtures of hydrocarbons, of which the most favourable influence on the properties of those oils posses the following: paraffinic hydrocarbons, isoparaffinic hydrocarbons of low flow temperature, naphthene hydrocarbons and alkylbenzenes with long alkyl chains (Kirk-Othmer, 2007).

After refining the following lube oil properties are changed (Sequeira, 1989, 1992; Kirk-Othmer, 2007):

- viscosity index - in the result of removal of aromatic compounds and some naphthene parts the viscosity index increases;

- viscosity - viscosity decreases because after an extraction process the amount of paraffins characterized by lower viscosity increases;

- pour point temperature - this parameter increases because of an increase of the paraffin amount in the obtained raffinate;

- colour - colour improvement results from the removal of resin compounds and other unsaturated chemical structures causing dark colour;

- smell;

- thermal-oxidative stability;

- contents of the remnants after both coking and incineration;

- content of polycyclic aromatic hydrocarbons and naphthene aromatic hydrocarbons with short side chains, content of sulphur, nitrogen and resin substances.

\section{Solvent extraction processes}

In order to change the group composition of fractions obtained from the distillation under reduced pressure, i.e. to decrease the content of polycyclic aromatic hydrocarbons, resins and heterocyclic compounds, they are submitted to the selective process of solvent refining. The heavy fractions (vacuum remnants) undergo an additional process of propane deasphaltizing (Pillon, 2007).

The improvement of the refined oil fractions properties to some degree depends on the ones of the primary feed stock (petroleum) and also on the type of the applied solvent. Since the base lubes obtained in the refineries considerably differ in their molecular compositions and physical properties resulting from the processed petroleum parameters, every refinery, individually, has to conduct a detailed analysis of a chosen lube fraction and laboratory investigation on adapting the parameters of a solvent refining process to the required quality of the obtained base lubes (Lynch, 2008; Speight, 2015).

As the result of an extraction process in the raffinate solution, the desired hydrocarbons, i.e. paraffinic, isoparaffinic and naphthene hydrocarbons, and the aromatic ones with one ring and long alkyl substituents are left. Whereas the highly condensed aromatic hydrocarbons, heterocylic compounds and resins will pass to the extract solution (Gary and Handwerk, 2001).

Organic solvents applied in the extraction processes should be characterized by (Sequeira, 1992; Tanasescu and Rosca, 2001):

- high selectivity allowing for:

- easy dissolution of aromatic hydrocarbons and polycyclic aromatic compounds and resins of low viscosity index,

- poor dissolution of paraffin hydrocarbons and naphthene hydrocarbons of high viscosity index ;

- good dissolution resulting with low ratio of solvent to the purified product;

- good thermal-oxidative stability, oxidized products should not be deposited in the equipment of the installation, especially in the extraction unit;

- high density allowing for or easy separation of the refining and extraction phases;

- low boiling temperature, to reduce the cost of the solvent distillation from raffinate and extract solutions;

- should not cause corrosion of the installation;

- should not be toxic;

- the price should be low.

For many years the research connected with the solvent extraction process has been concentrated on looking for effective, selective solvents for aromatic compounds extraction 
from vacuum distillates. Optimization of properties such as the content of aromatic substances, the pour point temperature and viscosity index is the main reason to choose the most effective solvent for the extraction process (Ghafil Alibrahem, 2010).

At present, furfural is the solvent most often applied in the refineries, since its selectivity is high enough in regard to aromatic compounds (Kirk-Othmer, 2007).

Drawbacks of furfural are: furfural gets oxidized, polymerized and creates azeotrope with water. Extraction processes with the use of this solvent lose their leading position to the advantage of extraction processes with the use of $\mathrm{N}$-methylpyrrolidone. NMP is characterized by good selectivity, low viscosity, low toxicity and better demulsification properties than furfural. Its drawbacks are both the high boiling temperature and price (Lynch, 2008; Gary and Handwerk, 2001).

In the paper published in 2008 the research on increasing the lube viscosity index by extracting the undesirable aromatic hydrocarbons which lower the vacuum fraction viscosity index was presented. The research was conducted with the use of furfural and $\mathrm{N}$-methylpyrrolidone. The investigation confirmed obtaining a higher quality raffinates and, at the same time, preserving the identical technological parameters of the extraction process conducted with N-methylpyrrolidone (Abdul-Halim and Amal Khalid Shehab, 2008).

Similar investigation was conducted at the Oil and Gas Institute - National Research Institute. The results of tests carried out on vacuum fractions obtained from the pipe line oil REBCO accessible on the local market confirmed a possibility of reaching a comparable level of raffinates quality by applying milder technological parameters of NMP refining than in the furfural extraction processes. This allowed to reduce the exploitation cost due to lowering the ratio of solvent to the feedstock and applying lower temperatures of the operation of the extraction column, at the same time keeping the quality of base lubes on the required level (Bartyzel, 2010, 2011a, 211b, 2012; Pelc et al. 1988, 1989).

\section{Extraction processes with the use of a co-solvent}

To increase the effectiveness and selectivity of solvent extraction processes an additive of a second solvent, also called co-solvent, can be applied. The co-solvent in the liquid-liquid extraction process, can increase the yield of extraction in two ways (Epelle et al., 2018):

- acting simultaneously to the main solvent;

- acting conversely to the main solvent.

In the first case the co-solvent is additive in relation to the extract and increases the extraction yield by creating an extract-solvent complex. In the second case the solvent is additive in relation to the raffinate. Here the second solvent increases the extraction yield by creating a raffinate-solvent complex, and the mixture obtains the stability level in a shorter time. The selectivity of the extraction process with the use of a co-solvent is very favourably effected by higher solubility of the co-solvent in one of the phases of the extract or raffinate (Ibtehal and Muslim, 2015; Luo et al., 2018).

The data concerning the liquid-liquid equilibrium in the non-mixing liquid system, especially those determining the critical temperature are essential in designing the extraction installations and calculating the thermodynamic boundary of the work of a particular process. The saturation equilibrium in the system: aromatic hydrocarbons - furfural has been quite widely described in the literature. The extraction of aromatic compounds from vacuum fractions with furfural in different temperatures and at different solvent to feed stock ratios was studied in detail (Espada et al., 2008; Hoseini et al., 2009).

Research on the selectivity of ion exchange with the use of co-solvent showed that an additive of light hydrocarbon compounds can increase the performance of aromatic compounds extraction (Fakhr Hoseini et al., 2009 ).

In 2003 an improved process of solvent extraction with an additive of furfural for vacuum distillates processed with the aim of obtaining base lubes by adding the co-solvent to the main solvent was presented. The function of the co-solvent was best fulfilled by aliphatic amides or mixtures of amides added to the basic solvent. The investigation showed that an addition of co-solvent makes the phases separate more easily, improves selectivity and increases the raffinate yield, at the same time preserving its quality on the constant level, what was confirmed with measurements of the raffinate refraction index. The presented results showed that in the case of extraction conducted at the solvent to feedstock ratio of 1,5:1, the co-solvent mixtures are more effective than furfural only, what resulted with three percent increase of refining yield at the same coefficient of raffinate refraction. $5 \%(\mathrm{~m} / \mathrm{m})$ increase of the raffinate yield was obtained for the solvent-feed stock ratio of 1.8:1, at the same time preserving the same value of the raffinate refraction coefficient (Patent US2003100813).

Also research on the use of 2,2,4-trimethylpentane as a cosolvent with furfural for aromatic hydrocarbon extraction from vacuum distillates was conducted (Yousef and Ahmed Muhammad, 2018).

To increase the extraction yield more than 6 weight $\%$ in relation to the raffinate obtained using $\mathrm{N}$-methylpyrrolidone only Raman and co-authors suggested the use of formamide as a co-solvent with $\mathrm{N}$-methylpyrrolidone. The applied co-solvent was chosen during the research on the introduction of a cosolvent from amid group into the solvent extraction (Patent US2010243533). The same year research on the improvement 
of properties of the base lube oils produced from vacuum distillates in Al-Daura Raffinery was conducted. Solvent extraction under atmospheric pressure was studied at different temperatures. In the investigation most important issue was to increase the yield of the raffinate. During these investigations different compositions of the solvent containing furfural and $\mathrm{N}$-methylpyrrolidone mixed in various proportions were applied. The best results were obtained for compositions containing from $80 \%(\mathrm{~m} / \mathrm{m})$ to $60 \%(\mathrm{~m} / \mathrm{m})$ of furfural and from $20 \%(\mathrm{~m} / \mathrm{m})$ to $40 \%(\mathrm{~m} / \mathrm{m})$ of $\mathrm{N}$-methylpyrrolidone. During the tests the viscosity index increased to 114 , and the refraction coefficient was decreasing with the increase of the raffinate yield. (Ghafil Alibrahem, 2010).

In the paper Extraction of Aromatic Hydrocarbons from Lube Oil Using Different Co-Solvent research on the effect of co-solvent on the process of solvent extraction of two kinds of fractions obtained from vacuum distillation installation in Daura refinery in Baghdad was presented. In this work formamide and $\mathrm{N}$-methylpyrrolidone mixed with furfural in different proportions were applied as co-solvents, to be used for a single-stage solvent extraction carried out in a glass bulb; the separation process was carried out in a glass separator. The process was studied in regard to the extraction temperatures from 70 to $110^{\circ} \mathrm{C}$ for formamide and from 80 to $120^{\circ} \mathrm{C}$ for $\mathrm{N}$-methylpirrolidone. The solvent - feed stock ratio was from 1:1 to 2:1 for the compositions of furfural with formamide and from 1:1 to 3:1 for furfural with NMP. The investigation results obtained by the authors show that the viscosity index of the base lube oil fraction increases, whereas the raffinate viscosity and performance per percent decrease with the increase of extraction temperature and of both the solvent/oil and co-solvent/furfural ratio. In order to obtain the best value of viscosity index $=102$, of the viscosity at the temperature $100^{\circ} \mathrm{C}=3.01 \mathrm{~mm}^{2} / \mathrm{s}$ and yield $69.23 \%(\mathrm{~m} / \mathrm{m})$, the best temperature for furfural was $90^{\circ} \mathrm{C}$, the best furfural/ co-solvent ratio 60:40 and that of solvent - vacuum fraction 1,5:1. The optimal parameters for the process with NMP used as a co-solvent were the following: the temperature of $110^{\circ} \mathrm{C}$, the solvent/vacuum fraction ratio 2:1 and the furfural/NNP ratio $60: 40$, allowing to obtain a raffinate of viscosity index 96 , viscosity at $100^{\circ} \mathrm{C}$ on the level of $9.10 \mathrm{~mm}^{2} / \mathrm{s}$ and yield $68.5 \%(\mathrm{~m} / \mathrm{m})$ (Ibtehal and Muslim, 2015).

\section{Characteristics of the investigated feedstock}

The feedstock applied in the investigation was a heavy fraction obtained from distillation of atmospheric remnants. The physicochemical properties of the feed stock to be investigated in a solvent refining process on a laboratory scale are presented in Table 1.
Table 1. Characteristics of fraction designated for investigation

Tabela 1. Charakterystyka frakcji C przeznaczonej do badań

\begin{tabular}{|l|c|}
\hline \multicolumn{1}{|c|}{ Denomination } & Feed stock \\
\hline \hline $\begin{array}{l}\text { Density in the temperature of } 90^{\circ} \mathrm{C} \text { as per PN-EN ISO } \\
\text { 12185:2002 }\left[\mathrm{kg} / \mathrm{m}^{3}\right]\end{array}$ & 881.3 \\
\hline $\begin{array}{l}\text { Kinematic viscosity in the temperature of } 100^{\circ} \mathrm{C} \text { as } \\
\text { per PN-EN ISO } 3104: 2004\left[\mathrm{~mm}^{2} / \mathrm{s}\right]\end{array}$ & 13.199 \\
\hline Kinematic viscosity in the temperature of $50^{\circ} \mathrm{C}$ as per & 88.60 \\
PN-EN ISO $3104: 2004\left[\mathrm{~mm}^{2} / \mathrm{s}\right]$ & 73 \\
\hline Viscosity index as per PN-ISO $2909: 2009$ & 1.4981 \\
\hline Refractive index in the temperature of $70^{\circ} \mathrm{C}$ as per & $\mathrm{D} 8.0$ \\
PN-81/C-04952 & \\
\hline Colour as per PN-ISO $2049: 2010$ & 40.7 \\
\hline Group composition as per PN-72/C-04025 $[\%(m / m)]$ & 23.3 \\
- paraffins-naphthenes & 8.0 \\
- aromatics $\mathrm{n}_{\mathrm{D}}{ }^{20}<1.53$ & 16.0 \\
- aromatics $\mathrm{n}_{\mathrm{D}}{ }^{20} 1.53-1.55$ & 4.0 \\
- aromatics $\mathrm{n}_{\mathrm{D}}{ }^{20} 1.55-1.59$ & 7.6 \\
\hline - aromatics $\mathrm{n}_{\mathrm{D}}{ }^{20}>1.59$ & 41 \\
\hline resins & \\
\hline Pour point temperature as per PN-ISO $2207: 2011\left[{ }^{\circ} \mathrm{C}\right]$ & \\
\hline
\end{tabular}

\section{The laboratory stand for solvent refining}

Large laboratory stands allowing to conduct solvent refining, simulating an industrial process conducted on the oil block of a petroleum refinery were used in the technological investigations.

The process of selective refining with either furfural or furfural with co-solvent of vacuum distillate was performed continuously on a large laboratory unit. Segments of the unit were electrically heated with continous temperature regulation. Furfural or furfural with a co-solvent was fed to the top, and the feedstock to the bottom of the unit, using a dozing laboratory plunger pump.

The total load of feedstock and solvent of the unit was kept at a constant level. The raffinate extract was collected from the top of the unit, and the extract solution from the bottom. In order to distill the solvents off the raffinate solutions, a distillation process with superheated steam stripping was introduced.

The efficiency of the extraction unit coresponds to 7 theoretical extraction stages. Both the raffinate and extract yield were assessed in relation to the amount of feedstock supplied for refining.

\section{Laboratory processes of continuous refining}

In order to compare the solvent refining processes either with furfural or furfural with a co-solvent it was decided to use the same process parameters for all laboratory tests. 
As the reference process refining with furfural was only regarded, with the optimum refining temperature (top of the unit), for proper refining process operations was $115^{\circ} \mathrm{C}$. Parameters of fraction solvent refining for all the conducted processes are presented below:

- $\quad$ solvent/feed stock ratio 3,0:1,0;

- unit bottom temperature $90^{\circ} \mathrm{C}$;

- unit top temperature $115^{\circ} \mathrm{C}$;

- unit load $3 \mathrm{~kg} / \mathrm{h}$.

The solvent refining processes conducted in laboratory conditions were carried out without disturbance, and the eyehole of the refining unit made it possible to observe the interphase boundary between the raffinate and the extract.

Regeneration of the solvent from both the raffinate and extract solutions was conducted using distillation process with superheated steam of the temperature of $125-135^{\circ} \mathrm{C}$.

\section{Assessment of the effect of the applied solvent additive on the performance and quality of the obtained raffinates}

Laboratory tests of extraction processes, with fraction as the feedstock, furfural as the main solvent and formamide as co-solvent, allowed to obtain samples of both raffinates and extracts. In regard to raffinate samples, physicochemical properties were assessed within the range typical for raffinates. The properties of the raffinate obtained during the process with furfural without a co-solvent were accepted as the reference point for assessment of all the other raffinates produced during refining with a co-solvent.

In Table 2 properties of raffinates obtained in laboratory tests are presented.

When analysing the obtained results it was stated that although the same technological parameters of extraction processes were applied, changing only the co-solvent proportion from 0 to $10 \%(\mathrm{~m} / \mathrm{m})$, raffinates of different performance and quality were obtained.

The reference process R1 with furfural only was characterized by the lowest performance of the raffinate obtained, on the level of $49.7 \%(\mathrm{~m} / \mathrm{m})$, but in the extraction processes in which the co-solvent in the proportions of $5 \%(\mathrm{~m} / \mathrm{m})$ and $10 \%(\mathrm{~m} / \mathrm{m})$ was applied, raffinates of performance of $62.5 \%(\mathrm{~m} / \mathrm{m})$ and $72.2 \%(\mathrm{~m} / \mathrm{m})$ adequately were obtained. The raffinates performances in relation to the amount of co-solvent were presented in Figure 1.

The increase in raffinate yield was connected with a proportional decrease of its quality in regard to all the investigated

Table 2. Properties of the obtained raffinates

Tabela 2. Właściwości uzyskanych rafinatów

\begin{tabular}{|c|c|c|c|}
\hline Identification number laboratory raffinate & R 1 & $\mathbf{R} 2$ & $\mathbf{R} 3$ \\
\hline \multicolumn{4}{|l|}{ Conditions of refining } \\
\hline - solvent & furfural & furfural $+5 \%$ formamide & furfural $+10 \%$ formamide \\
\hline - solvent ratio & $3: 1$ & $3: 1$ & $3: 1$ \\
\hline - temperature top/bottom of the unit $\left[{ }^{\circ} \mathrm{C}\right]$ & $115 / 90$ & $115 / 90$ & $115 / 90$ \\
\hline - unit load $[\mathrm{kg} / \mathrm{h}]$ & 3 & 3 & 3 \\
\hline - raffinate yield per load $[\%(\mathrm{~m} / \mathrm{m})]$ & 49.7 & 62.5 & 72.2 \\
\hline \multicolumn{4}{|l|}{ Properties } \\
\hline $\begin{array}{l}\text { Kinematic viscosity in the temperature of } 100^{\circ} \mathrm{C} \text { as per } \\
\text { PN-EN ISO } 3104: 2004\left[\mathrm{~mm}^{2} / \mathrm{s}\right]\end{array}$ & 9.173 & 9.941 & 10.553 \\
\hline $\begin{array}{l}\text { Kinematic viscosity in the temperature of } 50^{\circ} \mathrm{C} \text { as per } \\
\text { PN-EN ISO } 3104: 2004\left[\mathrm{~mm}^{2} / \mathrm{s}\right]\end{array}$ & 41.65 & 47.96 & 55.67 \\
\hline Viscosity index as per PN-ISO 2909 & 120 & 112 & 99 \\
\hline Refractive index $\mathrm{n}_{\mathrm{D}}{ }^{70}$ as per PN-81/C-04952 & 1.4642 & 1.4711 & 1.4769 \\
\hline Colour as per PN-ISO 2049:2010 & 2.5 & L 3.0 & L 3.5 \\
\hline $\begin{array}{l}\text { Group composition as per PN-72/C-04025 [\% }(\mathrm{m} / \mathrm{m})] \\
\text { - paraffins-naphthenes } \\
\text { - aromatics } \mathrm{n}_{\mathrm{D}}^{20}<1.53 \\
\text { - aromatics } \mathrm{n}_{\mathrm{D}}{ }^{20} 1.53-1.55 \\
\text { - aromatics } \mathrm{n}_{\mathrm{D}}{ }^{20} 1.55-1.59 \\
\text { - aromatics } \mathrm{n}_{\mathrm{D}}{ }^{20}>1.59 \\
\text { - resins }\end{array}$ & $\begin{array}{l}69.5 \\
29.6 \\
<0.1 \\
<0.1 \\
<0.1 \\
0.5\end{array}$ & $\begin{array}{c}58.3 \\
35.8 \\
<0.1 \\
<0.1 \\
<0.1 \\
4.2\end{array}$ & $\begin{array}{c}53.4 \\
28.1 \\
16.8 \\
<0.1 \\
<0.1 \\
1.6\end{array}$ \\
\hline
\end{tabular}




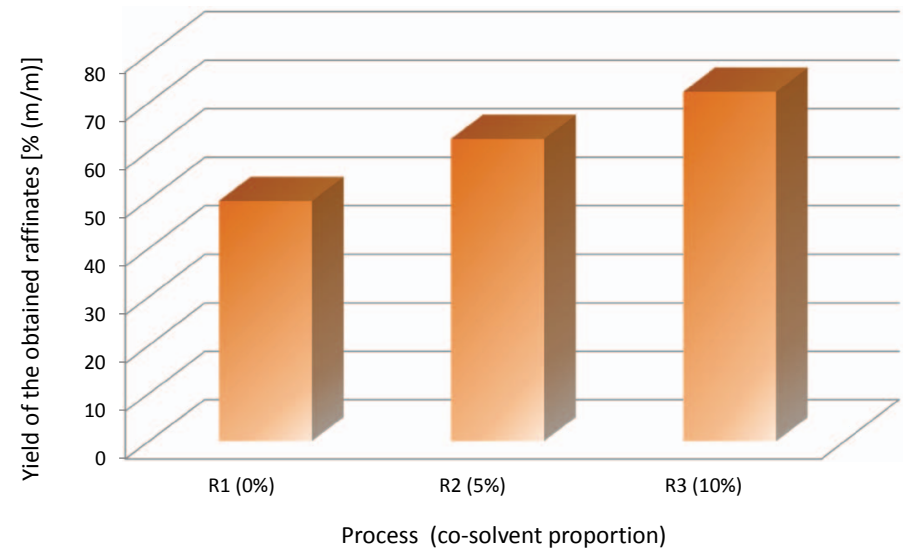

Fig. 1. Performances of raffinates in relation of the co-solvent amount

Rys. 1. Wydajności rafinatów w zależności od udziału współrozpuszczalnika

parameters. The basic parameter of the investigated raffinates is the viscosity index calculated basing on raffinate kinematic viscosity in the temperatures of $100^{\circ} \mathrm{C}$ and $50^{\circ} \mathrm{C}$. In the reference raffinate the lowest kinematic viscosity values of all the obtained raffinates were reached. In the temperature of $100^{\circ} \mathrm{C}$ kinematic viscosity value was $9.173 \mathrm{~mm}^{2} / \mathrm{s}$, and in the temperature of $50^{\circ} \mathrm{C}$ it was $41.65 \mathrm{~mm}^{2} / \mathrm{s}$. Basing on these values the highest viscosity index of 120 was obtained. For R 2 raffinate the value of kinematic viscosity in the temperature of $100^{\circ} \mathrm{C}$ was $9.941 \mathrm{~mm}^{2} / \mathrm{s}$, and in $50^{\circ} \mathrm{C}-47.96 \mathrm{~mm}^{2} / \mathrm{s}$. For these kinematic viscosity values the viscosity index was 112 . The lowest viscosity index of only 99 was characteristic for the raffinate obtained with about $10 \%(\mathrm{~m} / \mathrm{m})$ of co-solvent. This raffinate was also distinguished among others by the highest values of kinematic viscosity determined in the temperatures of $100^{\circ} \mathrm{C}$ and $50^{\circ} \mathrm{C}$.

Similarly, with the increase of the co-solvent proportion, colour deterioration, from L 2.5 for the raffinate obtained without a co-solvent, through L 3.0 for that obtained in the process with $5 \%(\mathrm{~m} / \mathrm{m})$ of formamide, to the worst colour value - L 3.5 for the raffinate obtained in the process with $10 \%$ of formamide was observed. The presented raffinate colour values were much lower than that determined for fraction, i.e. the feedstock to be refined.

The refractive index in $70^{\circ} \mathrm{C}$ also indicates deterioration of raffinate quality together with an increase of the co-solvent proportion in the extraction process. For the reference raffinate from R1 process the value of the refractive index was the lowest (1.4642). During the process with $5 \%(\mathrm{~m} / \mathrm{m})$ of co-solvent, a raffinate was obtained with the refractive index of 1.4711, whereas for the process with $10 \%(\mathrm{~m} / \mathrm{m})$ of a co-solvent the refractive index increased to the value of 1.4769 .

The changes of colour and of the refractive index in the obtained raffinates were presented in Figure 2 and 3.

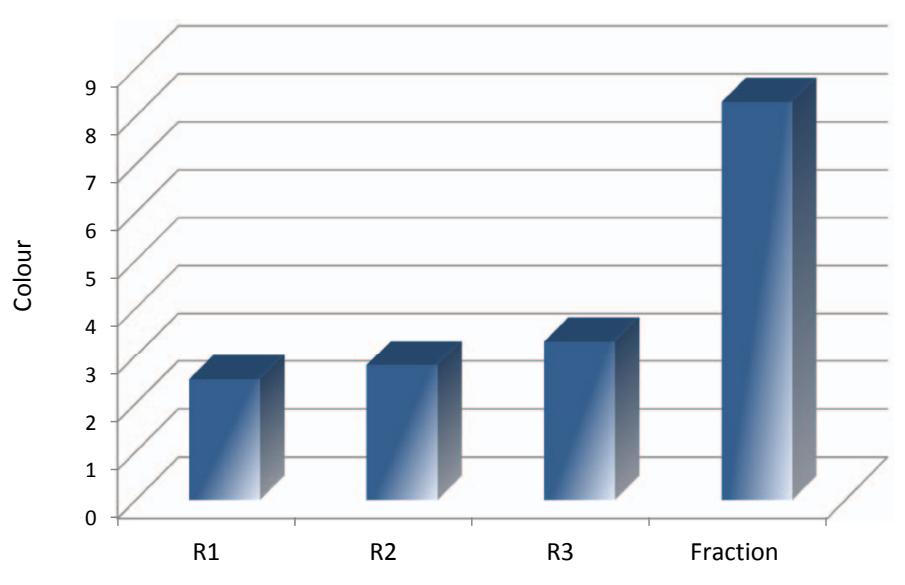

Fig. 2. Graphic presentation of the colour value determined both in the raffinates and the feedstock

Rys. 2. Graficzne przedstawienie wartości barwy oznaczonej w rafinatach i surowcu

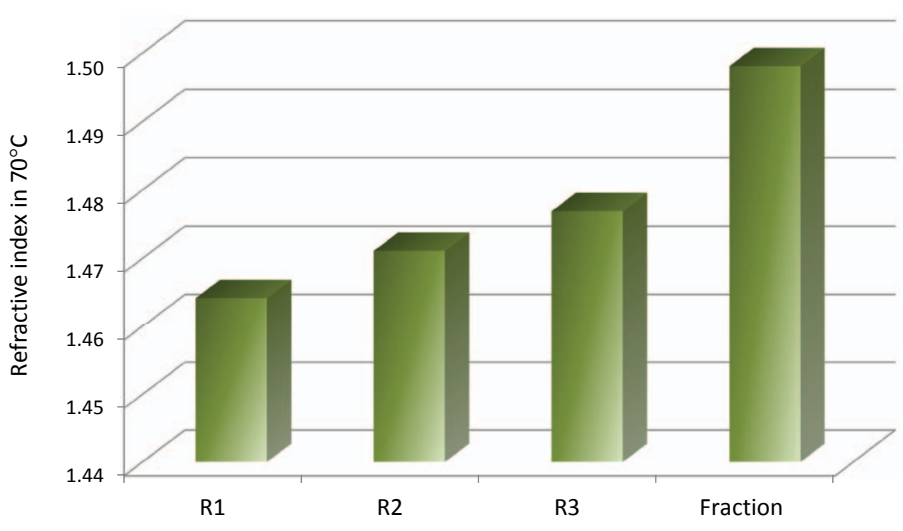

Fig. 3. Graphic presentation of the values of refractive index in $70^{\circ} \mathrm{C}$ determined both in the raffinates and the feedstock

Rys. 3. Graficzne przedstawienie wartości współczynnika załamania światła $\mathrm{w} 70^{\circ} \mathrm{C}$ oznaczonego $\mathrm{w}$ rafinatach i surowcu

Assessment of furfural selective activity together with the applied amount of a co-solvent was additionally based on the analysis of the group composition of obtained raffinates. This investigation was conducted using elutionchromatograph PN72/C-04025 method allowing to separate aromatic hydrocarbons into groups in relation to refractive index values. It has been conventionally accepted that the aromatic hydrocarbons of refractive index $\mathrm{n}_{\mathrm{D}}^{20}<1.53 \mathrm{i} \mathrm{n}_{\mathrm{D}}^{20} 1.53-1.55$ describe mono and bicyclic compounds, and aromatic compounds of $\mathrm{n}_{\mathrm{D}}{ }^{20}>1.55$ are characteristic of three and polycyclic aromatic hydrocarbons.

Presentation of the separation of the aromatic hydrocarbons into groups contained in both the obtained raffinates and the feed stock, is shown in Figure 4.

The obtained results confirm the selectivity of furfural without a co-solvent, extracting from the refined feed stock only small amounts of paraffin hydrocarbons and aromatic hydrocarbons of refractive index $\mathrm{n}_{\mathrm{D}}{ }^{20}<1.53$, but totally removing other aromatic hydrocarbons and leaving only a slight 
amount of resins. Furfural with $5 \%(\mathrm{~m} / \mathrm{m})$ of formamide addition was characterized by lower selectivity; during the process $11 \%(\mathrm{~m} / \mathrm{m})$ more of paraffinic hydrocarbons were produced, and more aromatic hydrocarbons of refractive index $\mathrm{n}_{\mathrm{D}}{ }^{20}<1.53$ and resins left. The worst selectivity when using furfural with $10 \%(\mathrm{~m} / \mathrm{m})$ of formamide. During that process the highest amounts of paraffin hydrocarbons were removed from the raffinate, the amount of hydrocarbons of $\mathrm{n}_{\mathrm{D}}{ }^{20}<1.53$ dropped slightly in relation to the reference raffinate R1369, but a considerable amount of aromatic hydrocarbons of $\mathrm{n}_{\mathrm{D}}{ }^{20} 1.53-1.55$ appeared.

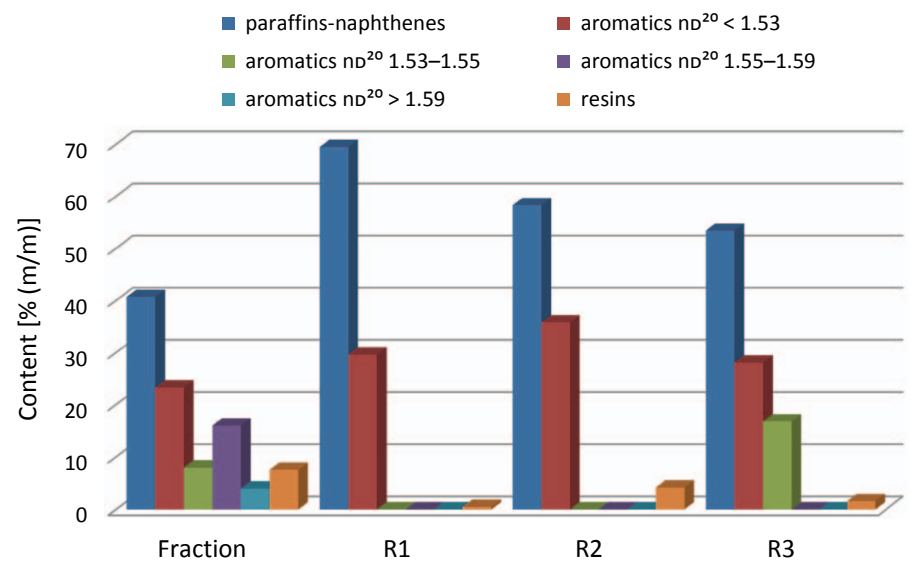

Fig. 4. Graphic presentation of the results of group compositions of both the feed stock and the obtained raffinates

Rys. 4. Graficzne przedstawienie wyników składów grupowych surowca oraz uzyskanych rafinatów

\section{Summary}

When analysing the obtained results it was observed that although the same technological parameters for extraction processes were used, changing only the percentage of the co-solvent from 0 to $10 \%(\mathrm{~m} / \mathrm{m})$, raffinates of different yield and quality were obtained. The lowest yield was noted for the processes with furfural only, being the reference process for those with a co-solvent. During that process a raffinate of $49.7 \%(\mathrm{~m} / \mathrm{m})$ yield was obtained. The highest raffinate yield on the level of $72.2 \%(\mathrm{~m} / \mathrm{m})$ was obtained for the process with $10 \%(\mathrm{~m} / \mathrm{m})$ of formamide. In the process with a co-solvent at the level of $5 \%(\mathrm{~m} / \mathrm{m})$ a raffinate of $62.5 \%(\mathrm{~m} / \mathrm{m})$ yield was obtained. Comparing the obtained raffinate yield values it can be stated that an additive of a co-solvent in the amount of $5 \%(\mathrm{~m} / \mathrm{m})$ will cause $12.8 \%(\mathrm{~m} / \mathrm{m})$ increase in the amount of the obtained raffinate, and an additive of the co-solvent in the amount of $10 \%(\mathrm{~m} / \mathrm{m})$ will bring $22.5 \%(\mathrm{~m} / \mathrm{m})$ yield increase of the refining process.

The increase of the raffinate yield was connected with a decrease of its quality in regard to all the investigated parameters, contrary to the data presented in the literature on the use of a co-solvent in the extraction process. These differences may be explained by variable susceptibility of vacuum distillates to refining depending on the type of crude oil. Majority of the papers describing the co-solvent influence on the refining process have been written in the Middle East and present the investigations conducted on vacuum distillates obtained from light crude oil. The investigations described in those papers were periodic, single stage tests, performed in laboratory glass. The investigations conducted by INiG - PIB were carried out on the laboratory refining unit, simulating the process of continuous solvent refining, and that also could have influenced the obtained results.

The paper was written on the basis of the statutory work entitled: The effect of the use of a co-solvent in the extraction process on the quality of the obtained raffinates - the work of the Oil and Gas Institute - National Research Institute was commissioned by the Ministry of Science and Higher Education; order number: 0072/ TO/2018, archive number: DK-4100-0072/2018.

\section{References}

Abdul-Halim A.-K. M., Amal Khalid Shehab A.-R., 2008. Viscosity Index Improvement of Lubricating Oil Fraction (SAE - 30). Iraqi Journal of Chemical and Petroleum Engineering, 9(3): 51-57.

Bartyzel A., 2010. Ocena wpływu zastosowania N-metylopirolidonu w procesie ekstrakcji ciągłej na jakość uzyskanych rafinatów i ekstraktów. Dokumentacja Instytutu Nafty i Gazu - Państwowego Instytutu Badawczego, $n r$ zlec. DK-4100-86/2010.

Bartyzel A., 2011a. Badania laboratoryjne procesów ciągłej ekstrakcji rozpuszczalnikowej. Nafta-Gaz, 2011, 9: 661-666.

Bartyzel A., 2011b. Badania procesu ekstrakcji rozpuszczalnikowej wysokoaromatycznych surowców naftowych przy zastosowaniu różnych rozpuszczalników organicznych. Dokumentacja Instytutu Nafty i Gazu - Państwowego Instytutu Badawczego, nr zlec. DK-4100-79/2011.

Bartyzel A., 2012. Badanie selektywności rozpuszczalników organicznych stosowanych w procesach ciągłej ekstrakcji rozpuszczalnikowej wysokoaromatycznych olejów naftowych. Nafta-Gaz, 10: 693-698.

Bushnell J.D., Fiocco R.J., 1980. Engineering aspects of the Exol N lube Process. Hydrocarbon Processing, 5: 119-123.

Czernożukow N.I., 1969. Rafinacja produktów naftowych. Wydawnictwa Naukowo-Techniczne, Warszawa.

Epelle E., Lukman Y., Otaru A.J., 2016. A comparative study of the solvent powers of phenol, furfuraland NMP in improving the viscosity index of spent lubricating oil. International Research Journal on Engineering, 3(1): 8-24. http://apexjournal.org/ irje/archive/2016/Apr/fulltext/Epelle\%20et\%20al.pdf (dostęp: październik 2018).

Espada J.J., Coto B., van Grieken R., Moreno J.M., 2008. Simulation of pilot-plant extraction experiments to reduce the aromatic content from lubricating oil. Chem. Eng. Process., 47: 13981403. https://www.sciencedirect.com/science/article/abs/pii/ S0255270107002097 (dostęp: październik 2018).

Fakhr Hoseini S.M., Tavakkoli T., Hatamipour M.S., 2009. Extraction of aromatic hydrocarbons from lube oil using n-hexane as a co-solvent. Separation and Purification Technology, 66(1): 
167-170. https:/www.sciencedirect.com/science/article/pii/ S1383586608004504?via\%3Dihub (dostęp: październik 2018).

Gary J.H., Handwerk G.E., 2001. Petroleum Refining Technology and Economics. Marcel Dekker, Inc.: 287-302.

Ghafil Alibrahem A., 2010. Evolutionary of extraction base oils unit's efficiency utilizing mixed solvent. Hydrocarbon Process, 88(9): 155-160.

Gurewicz I.L., 1975. Własności i przeróbka pierwotna ropy naftowej i gazu. Wydawnictwa Naukowo-Techniczne, Warszawa.

Hussein M., Amer A.A., Gaberah A.S., 2014. Used Lubricating Oils Re-Refining by Solvent Extraction. American Journal of Environmental Engineering and Science, 1(3): 44-50. https:// www.researchgate.net/publication/273386306_Used_lubricating_oils_re-refining_by_solvent_extraction (dostęp: październik 2018).

Ibtehal K.S., Muslim A.Q., 2015. Extraction of Aromatic Hydrocarbons from Lube Oil Using Different Co-Solvent. Iraqi Journal of Chemical and Petroleum Engineering, 16(1 ): 79-90.

Kirk-Othmer (ed.), 2007. Encyklopedia of Chemical Technology. Wiley J. and Sons, New York, 28.

Luo T., Zhang L., Zhang C., Ma J., Xu Z., Sun X., Zhao S., 2018. Role of water as the co-solvent in eco-friendly processing oil extraction: Optimization from experimental data and theoretical approaches. Chemical Engineering Science, 183(29): 275-287. https://www.sciencedirect.com/science/article/pii/ S0009250918301337?via\%3Dihub (dostęp: październik 2018).

Lynch T.R., 2008. Process Chemistry of Lubricant Base Stocks. Wyd. CRC Press, Taylor \& Francis Group, LLC: 141-168.

Pelc L., Wróblewska B., Dettloff R., Szewczyk A., Kaczmarczyk A., Sęk K., 1989. Badania nad rozeznaniem możliwości intensyfikacji procesu selektywnej rafinacji olejów dla G.Z.R. w wyniku zastąpienia furfurolu N-metylopirolidonem. Etap II. Dokumentacja Instytutu Technologii Nafty nr 2184/1989.

Pelc L., Wróblewska B., Dettloff R., Szewczyk A., Sęk K., 1988. Badania nad rozeznaniem możliwości intensyfikacji procesu selektywnej rafinacji olejów dla G.Z.R. w wyniku zastąpienia furfurolu N-metylopirolidonem. Etap I. Dokumentacja Instytutu Technologii Nafty $n r$ 2083/1988.

Pillon L.Z., 2007. Interfacial Properties of Petroleum Products. Wyd. CRC Press, Taylor \& Francis Group, LLC.

Podniało A., 2002. Paliwa oleje i smary w ekologicznej eksploatacji. Wydawnictwa Naukowo-Techniczne, Warszawa.
Sequeira A., 1989. Lubrication Base Oil Processing. Lubrication, 75(1): 5-16.

Sequeira A., 1992. Lubricating Oil Manufacturing Processes. Petroleum Processing Handbook, Marcel Dekker, New York: 634-664.

Sequeira A., 1994. Lubricant Base Oil and Wax Processing. Marcel Dekker, Inc.: 81-118.

Speight J., 2015. Fouling in Refineries. Elsevier Store: 226-227.

Tanasescu C., Rosca P., 2001. Rafinacja olejów bazowych metodą ekstrakcji n-metylopirolidonem. Nafta-Gaz, 3: 153-159.

Yousef N.S., Ahmed Muhammad A., 2018. Dearomatization of lube oil using polar solvents. International Journal of Scientific \& Engineering Research, 9(3), https://www.ijser.org/researchpaper/Dearomatization-of-lube-oil-using-polar-solvents.pdf (dostęp: październik 2018).

\section{Patenty}

Patent US2003100813 Extraction of aromatics from hydrocarbon oil using furfuralco-solvent extraction process. Publ. 29.05.2003.

Patent US2010243533 Extraction of aromatics from hydrocarbon olusing n-methyl2-pyrrolidone and co-solvent. Publ. 30.09.2010.

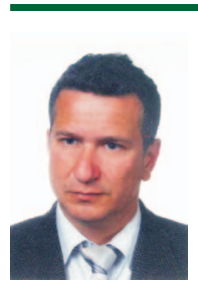

Artur ANTOSZ M.Sc. Eng.

Senior Research and Technical Specialist at the Department of Oils, Lubricants and Bitumen Oil and Gas Institute - National Research Institute 25 A Lubicz St.

31-503 Krakow

E-mail: artur.antosz@inig.pl

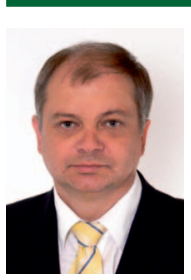

Stefan PTAK M.Sc. Eng.

Chief Engineering and Technical Specialist Head of the Department of Oils, Lubricants and Bitumen

Oil and Gas Institute - National Research Institute

25 A Lubicz St., 31-503 Krakow

E-mail: stefan.ptak@inig.pl 